\title{
The Age of the Bellows Dune Site O18, O'ahu, Hawai'i, and the Antiquity of \\ Hawaiian Colonization
}

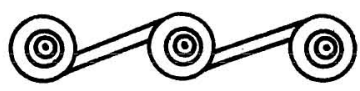

\section{H. DAVID TUGGLE AND MATTHEW SPRIGGS}

A FEW YEARS AGO a consensus developed among Hawaiian archaeologists that the initial Polynesian colonization of the archipelago occurred in the A.D. 100500 range (Chun and Spriggs 1987; Hunt and Holsen 1991; Kirch 1985:87, 298; Tuggle 1979:189), with the language used by the various authors clearly indicating a preference for the early end of the range. ${ }^{1}$ However, the consensus has now disintegrated, with some archaeologists holding the line on the early age (e.g., Cordy 1996; Graves and Addison 1995) and others arguing for colonization sometime after A.D. 600 (Spriggs and Anderson 1993) and in some cases as late as A.D. 800 (at least for O'ahu: Athens and Ward 1993; Athens et al. 1999). Graves and Addison (1995) refer to these as the "long" and "short" chronologies. ${ }^{2}$ Taken at their extremes, these two positions represent a discrepancy of as much as 700 years for the proposed settlement of Hawai'i (that is, c. A.D. 100 vs. C. A.D. 800 ).

The argument for a short chronology has developed as a result of two major factors: (1) new data derived from wetland coring, and (2) the re-evaluation of archaeological dates and dating methods.

Wetland coring provides a set of data that defines the beginnings of human modification of the landscape, and thus is related to the dating of colonization but is independent of cultural sites. For O'ahu, a substantial amount of coring data have been accumulated that are consistent in suggesting human presence in the environment around A.D. 800 or later (Athens 1997; Athens and Ward 1993; Athens et al. 1999).

For the dating of archaeological sites, the long chronology was developed in the 1970s based not only on radiocarbon but on volcanic glass hydration as well (see Emory and Sinoto 1969; Kirch 1974, 1985, 1986; Tuggle et al. 1978). For volcanic glass dating, a detailed review in the late 1970s indicated that the basis for age calculation of the hydration of Hawaiian volcanic glass was scientifically spurious and possibly had been fraudulently developed and applied (Tuggle and

H. David Tuggle is affiliated with the International Archaeological Research Institute, Inc., in Honolulu, and Matthew Spriggs is Head of School, School of Archaeology and Anthropology, Australian National University, Canberra. 
Olson 1978). Volcanic glass hydration gradually dropped from use as a dating method in Hawai'i, and is now seldom if ever cited in the arguments for early Hawaiian settlement (see, for example, Cordy 1996; Graves and Addison 1995). Radiocarbon dating has, of course, continued with numerous refinements, but a recent reconsideration of early radiocarbon dates for Hawai'i indicates that problems of provenience, analysis, and interpretation leave little support for early settlement in Hawai' $i$ in general (Spriggs and Anderson 1993) or at specific sites that had been included in the category of early settlement (Dye 1992; Spriggs 1991; Tuggle 1997).

One of the critical sites in the models of the colonization of Hawai' $i$ is O18, Bellows, O' $\mathrm{ahu}^{3}$ (Kirch 1985:298). The present paper is a site-specific analysis of the chronometric data from this site, including presentation of newly obtained radiocarbon determinations.

\section{BELLOWS OI8: ITS PLACE IN HAWAIIAN ARCHAEOLOGY}

Bellows Dune site O18 (now Hawai'i State Site 4852, Location O18) ${ }^{4}$ is located at the mouth of Waimānalo Stream (this is a modern name for the stream known traditionally as Puhā) located on the windward side of O'ahu (Figs. 1 and 2). It is well known for its status as an "early site" and clearly matches the model of where early sites should be: it lies in a rich windward environment, adjacent to a permanent stream. It was first excavated in 1967, and in the summary site report (Pearson et al. 1971), the radiocarbon determinations are interpreted to indicate a total occupational span for the site of A.D. 600-1100, although the authors point out the numerous problems with the dates and are careful not to suggest a specific date for the first occupation of the site.

The unusual artifactual assemblage at the site also suggested early occupation, and both sets of data compared favorably to the information from the sites at $\mathrm{Ka} \mathrm{La}$ 'e (H1 and H8), island of Hawai' $\mathrm{i}$, the prevailing primary cases for an early

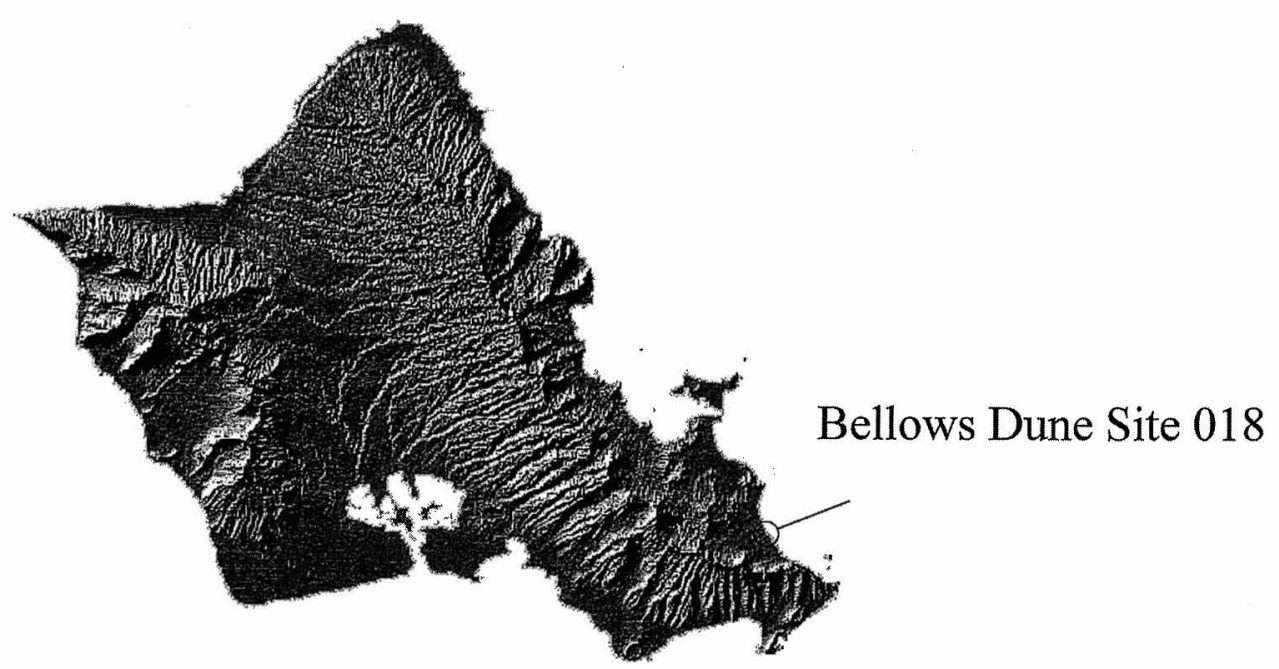

Fig. 1. Island of O'ahu, with location of the Bellows Dune site O18. 


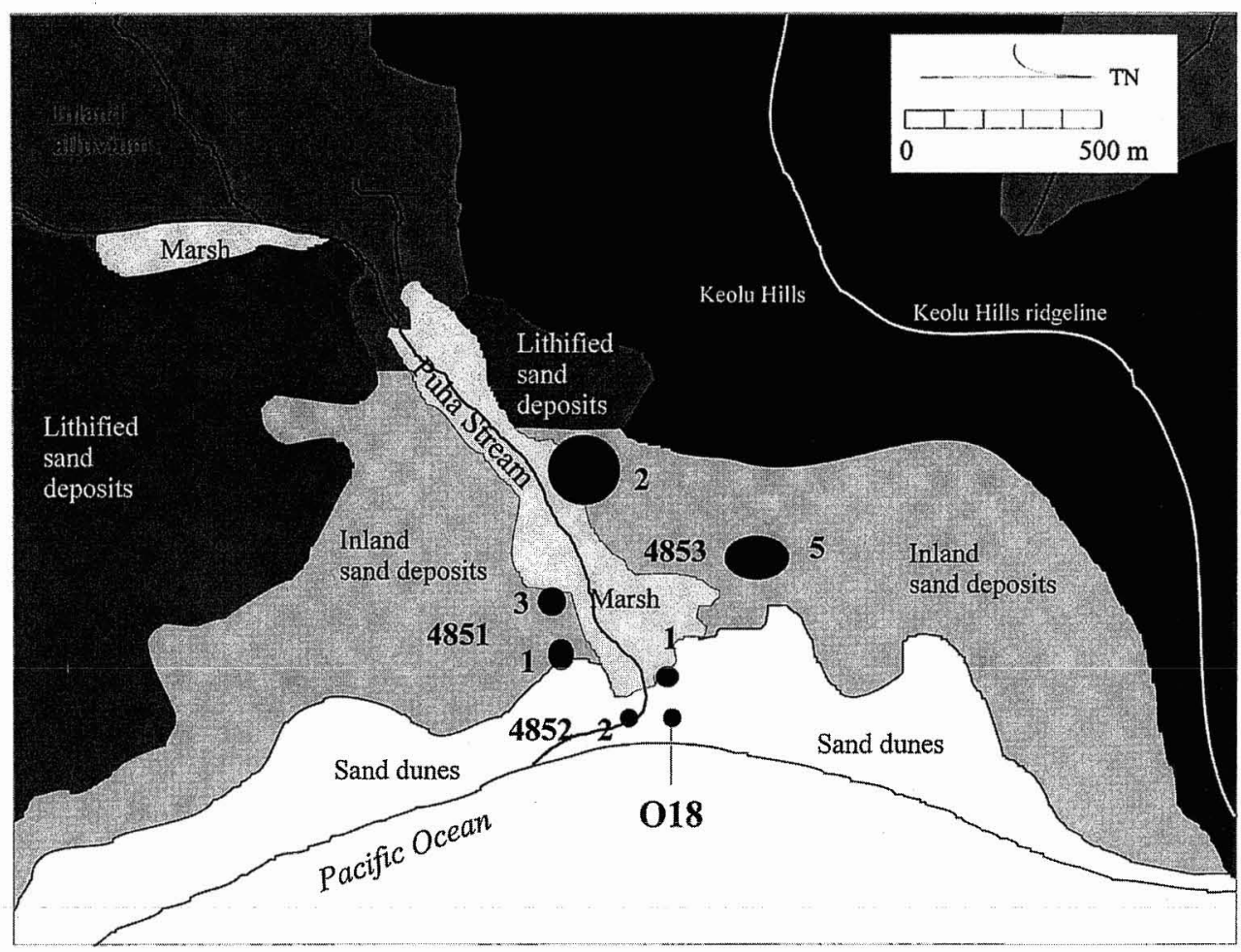

Fig. 2. Waimānalo area, Puhā Stream, and sites O18, 4851, 4852, and 4853.

settlement phase in Hawai'i. Site O18 was concluded to be "representative of an incipient stage in the development of Hawaiian culture as distinct from protoEast Polynesian culture" (Pearson et al. 1971:232), and thus became a type site for early Hawaiian settlement (Kirch 1974; Tuggle 1979). The site was also striking because it contained evidence for status differentiation in the form of a traditional symbol of royalty, the lei niho palaoa (a whale tooth pendant), found associated with a child's burial-thus placing this important cultural feature in an early time frame.

The report on the O18 site thus made several important points, implicitly or explicitly, related to chronology and settlement. Artifacts indicated that the site was early in the Hawaiian sequence, but that it was not a "first settlement." Radiocarbon dating could not really be used to provide a specific date of occupation, although it could be used to support a generally "early" age. And the artifacts and dated charcoal samples derived from a settlement, not from isolated contexts, fields, or otherwise dubious proveniences.

Another excavation at O18 was conducted in 1975 (Cordy and Tuggle 1976). At that time it was found that a substantial portion of the original dune deposit had been removed. ${ }^{5}$ Excavations, which were centered on the inland side of the dune, produced limited artifactual material, none of which matched the unusual assemblage from the previous work.

Subsequently, a detailed dating study of volcanic glass from both excavations 
was carried out for comparative chronology building and to provide an independent chronological base for the "early" assemblage from the first O18 excavations that might resolve problems with the ambiguous radiocarbon dating (Tuggle et al. 1978). The resulting hydration "dates" suggested an initial settlement at O18 in the A.D. 323-447 range. This was generally considered as a reasonable date for settlement (e.g., Kirch 1985:71), and in fact the volcanic glass dates for the O18 layers became the basis for the accepted chronology of the site. Subsequently, additional seemingly early radiocarbon dates from other locales on O'ahu helped solidify this age range as a date of settlement, and the long chronology became generally accepted for Hawaiian settlement.

However, an evaluation of the dating of individual sites indicates three critical points in the debate of the short vs. long chronology.

First, prior to 1985 there were only two sites known in Hawai'i that fell into this early range. In Kirch's (1985:298) presentation of a cultural sequence for Hawai' $i$, he notes that "only two archaeological components can be assigned to this initial period," that is, the Colonization period, dated from A.D. 300-600. These components are L. III at Bellows O18, and L. III in the Pu'u Ali'i dune site (H1) at South Point, Hawai'i.

Second, as volcanic glass dating fell into disrepute and disuse, little attention was paid to the fact that at O18, the O'ahu type site for early settlement, the chronometric basis for this assessment had devolved back to dependence on a set of problematic radiocarbon dates that was never originally used to define a precise early occupational date.

Third, since 1985, all of the seemingly new "good" early radiocarbon dates are associated with "bad" sites (that is, there are no identified substantial settlement sites with appropriately archaic-looking assemblages among them). ${ }^{6}$ With 30 years of work in Hawai'i since the excavation at O18, no new "Bellows" has emerged. The important site of Bellows O18 thus deserves yet one more evaluation.

\section{ABSOLUTE CHRONOLOGY: RADIOCARBON}

The excavations at Bellows O18 identified two extensive cultural layers, L. II and L. III ${ }^{7}$ (Fig. 3), separated by sterile sand (but with some features or disturbances intruding from L. II into III), with localized subdivisions of these two deposits created by bands of sand, resulting in a total of five cultural layers: II, IIa, IIIa, IIIb, and IIIc.

Ten radiocarbon samples from the dune proper (the 1967 excavation area) have been dated, with one additional sample derived from a trench (TR5) on the back side of the dune (Table 1 and Fig. 4). Five of the dune dates were obtained soon after the 1967 excavations and were included in the excavation report (Pearson et al. 1971). The additional five dates were derived from curated samples obtained in 1986 (Spriggs 1991; Spriggs and Anderson 1993), but never previously published in their entirety.

The first set of dates from O18 was plagued with problems, not the least of which was that an analytically modern date (GaK-1820, "younger than 380 years") came from the lower cultural layer (L. III), and the oldest determination (GaK-1819, "1600 \pm 90 B.P.") came from the upper layer (L. II). In the original 


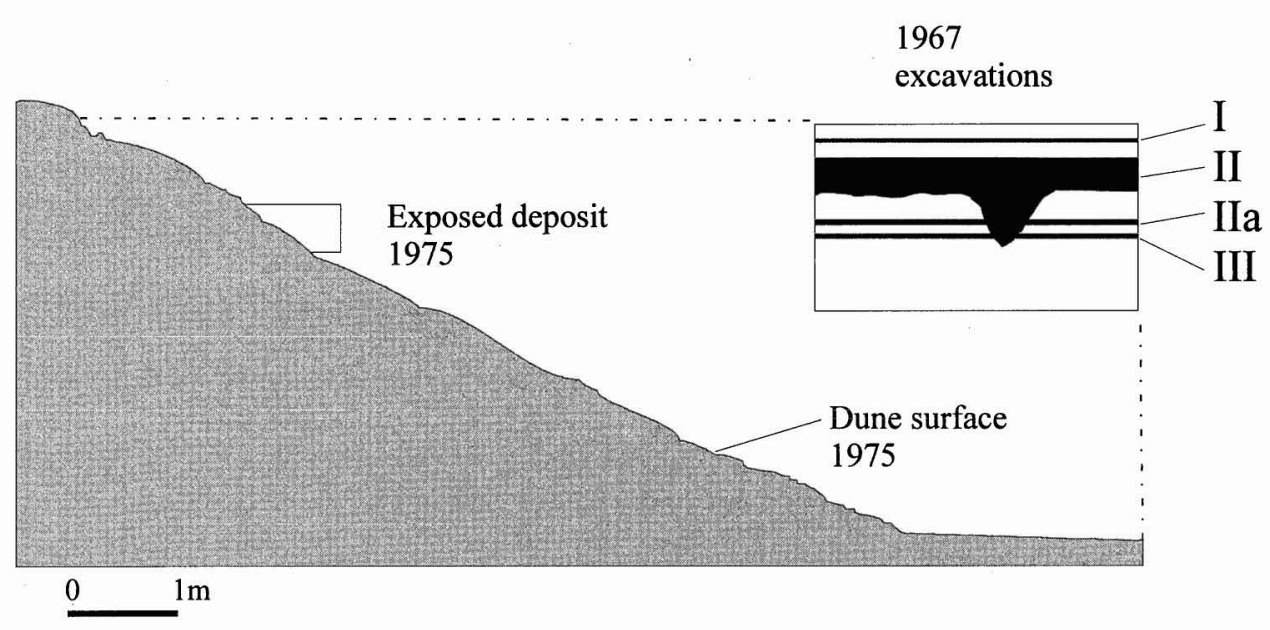

Fig. 3. Stratification of the Bellows Dune site.

analysis of the dates GaK-1820 was removed from consideration as obviously "contaminated" (Pearson et al. 1971:230). The other dated samples were put into a sequence based on the extreme overlap at two- or three-sigma, and then the entire set used to define the occupation span for the site without specifying the ranges of the two main layers or any subdivisions.

Subsequently Kirch and others have noted that the Gakushuin Laboratory that processed the samples had a history of producing anomalous dates, which compared poorly with those run by other laboratories (Kirch 1984:73; Spriggs 1989, 1999). A review of the excavation report and field notes also indicated problems with the field records and summaries (Cordy and Tuggle 1976) and thus some of the difficulty with the dates may have come from misinterpretation of the stratigraphic profiles (e.g., failing to note disturbances) as well as from mixing or misrecording of proveniences. One specific case that suggests such problems is the sample for GaK-1816 that was attributed to L. III, but may have come from L. II. The GaK-1816 sample came from a fire pit (or flake concentration? see footnotes for Table 1) superimposed over Feature 53. Both features were originally assigned to L. III, but later analysis indicated they probably originated in L. II (Cordy and Tuggle 1976).

Retrospectively, other difficulties are associated with the dates, most being common problems of the era. These include the use of scatter charcoal from midden or pits (some of which may be secondary fill of unknown origin), and the absence of wood identification to isolate potential driftwood or long-lived species. Trees or logs from North America drift to Hawai' $i$, a fact recorded as early as 1793 when Vancouver encountered a $61.5 \mathrm{ft}$ canoe between Kaua'i and O'ahu, determined that it was made of a pine log, and observed "as the natives informed us it was drifted by the ocean, it is probably the growth of some of the northern parts of America" (Vancouver 1798: III : 886-887). Hall (1839:111) reports two large North American driftwood logs being cut by native Hawaiians at Waimānalo. It is noteworthy that exotic woods have also been found in collections of archaeological charcoal from precontact deposits (Murakami 1987). A priori, one 
Table i. Bellows Dune Site: Radiocarbon Dates

\begin{tabular}{|c|c|c|c|c|c|c|c|c|c|c|}
\hline $\begin{array}{l}\text { RADIOCARBON } \\
\text { NO. }\end{array}$ & LAYER & $\begin{array}{l}\text { EXCAV. } \\
\text { UNIT }\end{array}$ & $\begin{array}{l}\text { COLLECTION } \\
\text { UNIT }\end{array}$ & $\begin{array}{l}\text { QUANTITY } \\
\quad(\mathrm{gm})\end{array}$ & MATERIAL $^{\mathrm{a}}$ & $\begin{array}{c}\text { MEASURED }{ }^{14} \mathrm{C} \\
\text { AGE (B.P.) }\end{array}$ & $\begin{array}{l}{ }^{13} \mathrm{C} /{ }^{12} \mathrm{C} \\
\text { RAtio } \%{ }^{b}\end{array}$ & $\begin{array}{c}\text { CONVENTIONAL } \\
\text { AGE (B.P.) }\end{array}$ & $\begin{array}{l}\text { CALIBRATED } \\
\text { AGE (A.D.) } 2 ?^{c}\end{array}$ & REFS. \\
\hline GaK-1818 & II & A-3 & $\begin{array}{l}\text { Scatter in pit } \\
\text { fill, burial } \\
\text { pit } 3\end{array}$ & $?$ & C-unid & $1110 \pm 120$ & NA & $1126 \pm 124$ & $661-1182$ & (1) \\
\hline GaK-1819 & II & A-20 & $\begin{array}{l}\text { Scatter in } \\
\text { deposit }\end{array}$ & $?$ & C-unid & $1600 \pm 90$ & NA & $1616 \pm 96$ & $235-644$ & (1) \\
\hline B-20852a & II & B-4 & $?$ & 0.9 & C-unid & $720 \pm 130$ & $-24.1 \pm 0.2$ & $720 \pm 130$ & $1028-1441$ & $(2)$ \\
\hline B-20852b & II & B-4 & $?$ & 1.7 & Kukui & $1350 \pm 230$ & $-36.4 \pm 0.2$ & $1330 \pm 230$ & 244-1198 & (2) \\
\hline GaK-1816 & $\begin{array}{l}\text { II or } \\
\text { II }^{\mathrm{d}}\end{array}$ & $\mathrm{A}-4^{\mathrm{e}}$ & Fire pit? & $?$ & C-unid & $700 \pm 125$ & NA & $716 \pm 129$ & $1030-1442$ & (1) \\
\hline GaK-1817 & $\begin{array}{l}\text { IIIa or } \\
\text { IIIb }\end{array}$ & N-9 & Fire pit? & $?$ & C-unid & $1030 \pm 110$ & NA & $1046 \pm 115$ & $723-1237$ & (1) \\
\hline GaK-1820 & III & A-4 & $\begin{array}{r}\text { Scatter in } \\
\text { deposit }\end{array}$ & $?$ & C-unid & $\begin{array}{c}\text { Younger than } \\
380 \text { years }\end{array}$ & NA & Modern & Modern & (1) \\
\hline B-20853 & IIIc? & N-9 & $?$ & 3.5 & C-unid & $1070 \pm 370$ & $-25.0 \pm 0.2$ & $1070 \pm 370$ & 234-1631 & $(2)$ \\
\hline ANU-6179 & III & B-1 & Scatter? & 0.8 & C-unid & $101.1 \pm 1.6 \% \mathrm{M}$ & $-24.8 \pm 0.2$ & $101.2 \pm 1.5 \% \mathrm{M}$ & Modern & (3) \\
\hline ANU-7027 & III & EE-14 & ? & 1.2 & Cocos nucifera $\mathrm{g}$ & $98.7 \pm 1.6 \% \mathrm{M}$ & $-23.1 \pm 0.2$ & $120 \pm 132$ & 1519-1955 & (4) \\
\hline B-20854 & ? & TR5, F1 & Pit & 13.1 & C-unid & $390 \pm 50$ & $-24.2 \pm 0.2$ & $320 \pm 50$ & $1452-1952$ & (2) \\
\hline
\end{tabular}

References: (1) Pearson et al. 1971:230; (2) Spriggs 1987, 1991; also see Hunt and Holsen 1991; Spriggs and Anderson 1993; (3) Radiocarbon Dating Research, Australian National University, letter report of October 27, 1988, results recalculated in 1996 by ANU based on revised ${ }^{13} \mathrm{C}$ measurement; (4) Radiocarbon Dating Research, Australian National University, letter report of October 10, 1990; results recalculated in 1996 by ANU based on revised ${ }^{13} \mathrm{C}$ measurement.

a Material; C-unid = charcoal, unidentified.

${ }^{\mathrm{b}} \mathrm{NA}=$ not available. For these dates CALIB calibration was employed using an assumed ${ }^{13} \mathrm{C} /{ }^{12} \mathrm{C}$ ratio of $-25 \mathrm{mil}$.

${ }^{c}$ Note that these dates are calibrated or recalibrated from the original published sources with CALIB 3.0 (Stuiver and Reimer 1993).

${ }^{\mathrm{d}}$ Pearson et al. (1971: Fig. 13) identify the provenience as L. III. The date comes from carbon from a fire pit that is superimposed on Burial 5. Analysis of original drawings and photographs suggests that the Burial 5 pit originates in L. II (Cordy and Tuggle 1976), and if this is true, dated charcoal from feature above the burial pit is also from L. II.

${ }^{\mathrm{e}}$ In Pearson et al. (1971) provenience is given as Unit A-4 (Fig. 13) and as Unit B-4 (Fig. 7).

${ }^{f}$ In Pearson et al. (1971) the associated feature is identified as a fire pit (Figure 13) and as a flake concentration (Table 2).

Identified by H. McEldowney, 1989. 
018

Layer

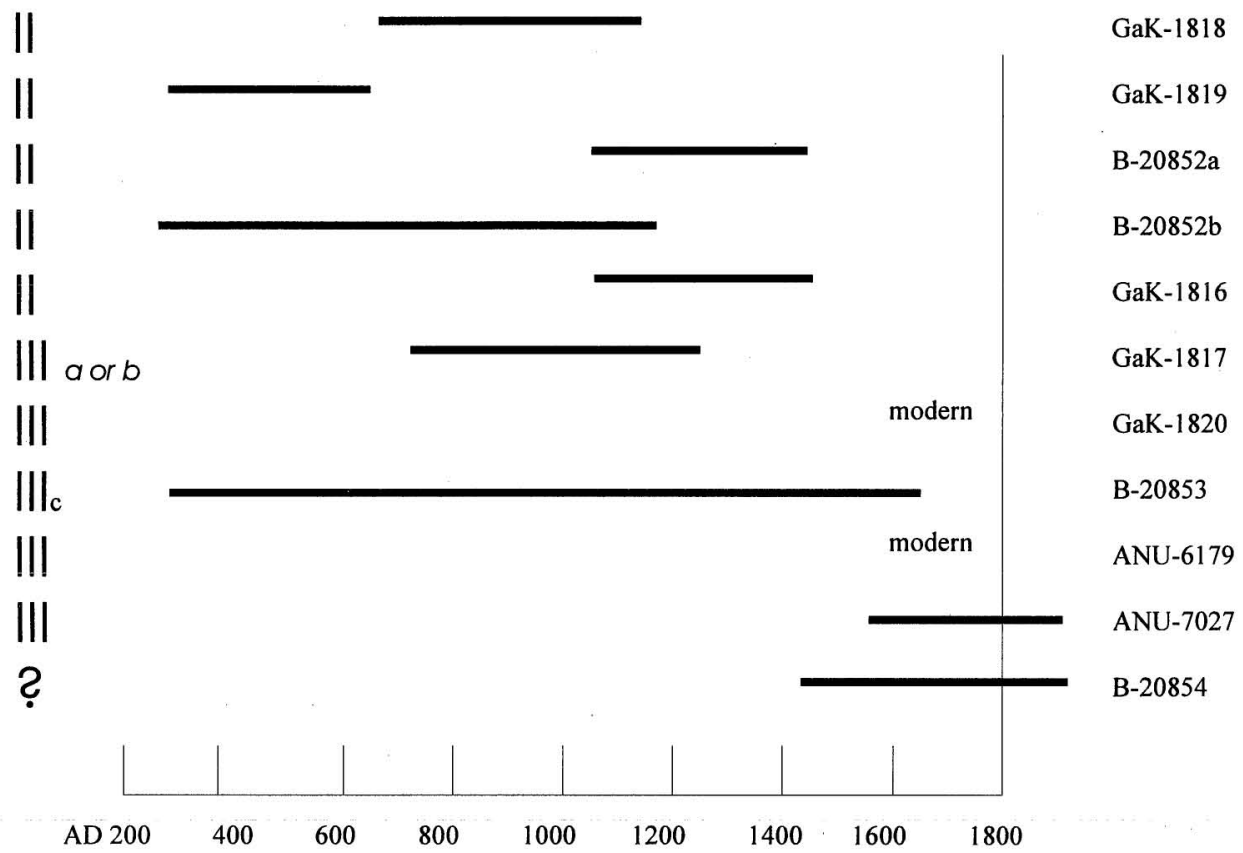

Fig. 4. Bellows Dune site, radiocarbon dates.

would expect a substantial amount of driftwood to be on Hawaiian shores at the time of human arrival, and that this would have been one of the primary sources of firewood.

The second set of five samples dated in the late 1980s does not provide a happy resolution to the dating problem of Bellows O18. Three samples from L. III were submitted (see Table 1: ANU-6179 and ANU-7027), of which two produced modern dates and the third (B-29853) yielded an excessively large error factor. The two modern dates from L. III charcoal support the previous suggestions that the problems with dating go beyond the Gakushuin and old wood factors, and include either provenience error or serious contamination, or both.

Two samples from L. II were submitted, one of charcoal (B-20852a) and the other kukui nut shell (Aleurites moluccana; sample B-20852b). These two samples are from the same provenience, but their calibrated date ranges overlapped only minimally. One date (B-20854) was obtained from a 1975 excavation in the inland side of the dune, but in a position that could not be stratigraphically related to the main deposits. The date of A.D. 1452-1952 does not place it in an "early" range.

Given this Laocoön-like tangle of chronological problems it is tempting to discard the whole lot outright, ${ }^{8}$ but something may be salvaged, depending on the fineness of the criterion sieve. ${ }^{9}$ If criteria for rejection are only stratigraphic inversion and modern dates, then five dates are rejected, leaving the pattern shown in Figure 5. This provides a time break between L. II and L. III around A.D. 1000 . 


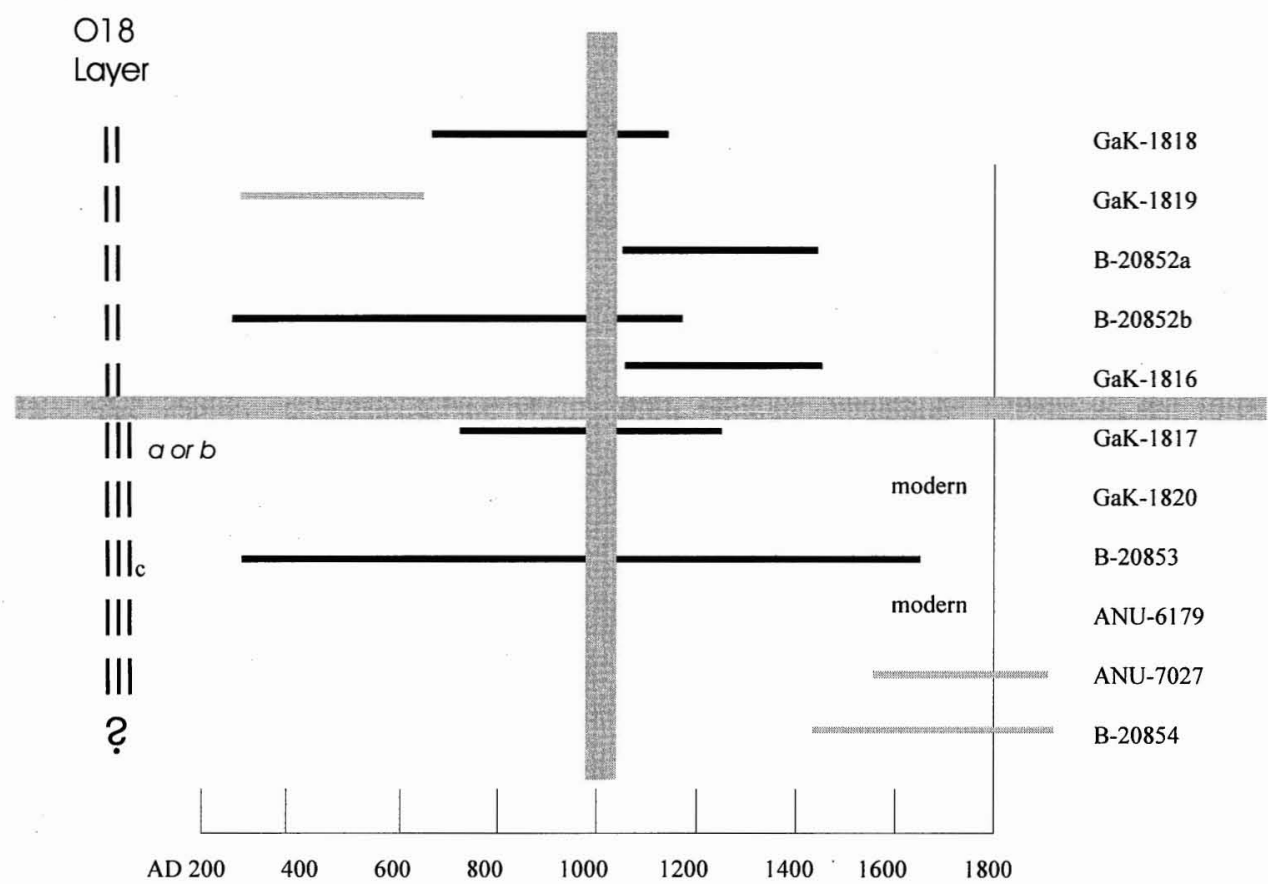

Fig. 5. Evaluated radiocarbon dates for the Bellows Dune site, set 1. The black lines represent acceptable dates, the gray lines represent dates rejected by inversion or modern.

Additional criteria for rejection include all Gakushuin dates as inherently flawed and all dates that have an excessive time span (e.g., defined as over half the original total radiocarbon age range for the deposit-A.D. 300-1950, which would include B-20852b and B-29853), resulting in only a single acceptable date, A.D. 1028-1441 (B-20852a), obtained from charcoal in L. II (Fig. 6).

\section{The Dating of Layers}

There are five dates for L. III (see Table 1 and Fig. 4). One (B-29853) has an excessive age range, and three are "modern." Two of the "modern" dates are from samples run in the late 1980s, and the laboratory report suggests that it is extremely unlikely that collection contamination is involved. At the same time, this suggests that the "modern" GaK date is not necessarily a result of laboratory error. The three samples apparently represent modern charcoal. What accounts for this is simply unknown. ${ }^{10}$

This leaves a single determination from L. III (GaK-1817) that might be acceptable, based on the date itself, although it bears the burden of being a GaK date. In its favor, however, it is not scatter charcoal, but from a defined feature. ${ }^{11}$ The range of the single date for L. III is A.D. 723-1237.

For L. II there are five dates (apparently none of which is associated with L. IIa). Three of these are the original Gakushuin dates, one of which (GaK-1819) has the earliest date range recorded from O18, A.D. 235-644, and is thus stratigraphically anomalous. This date has to be considered either an erroneous $\mathrm{GaK}$ 


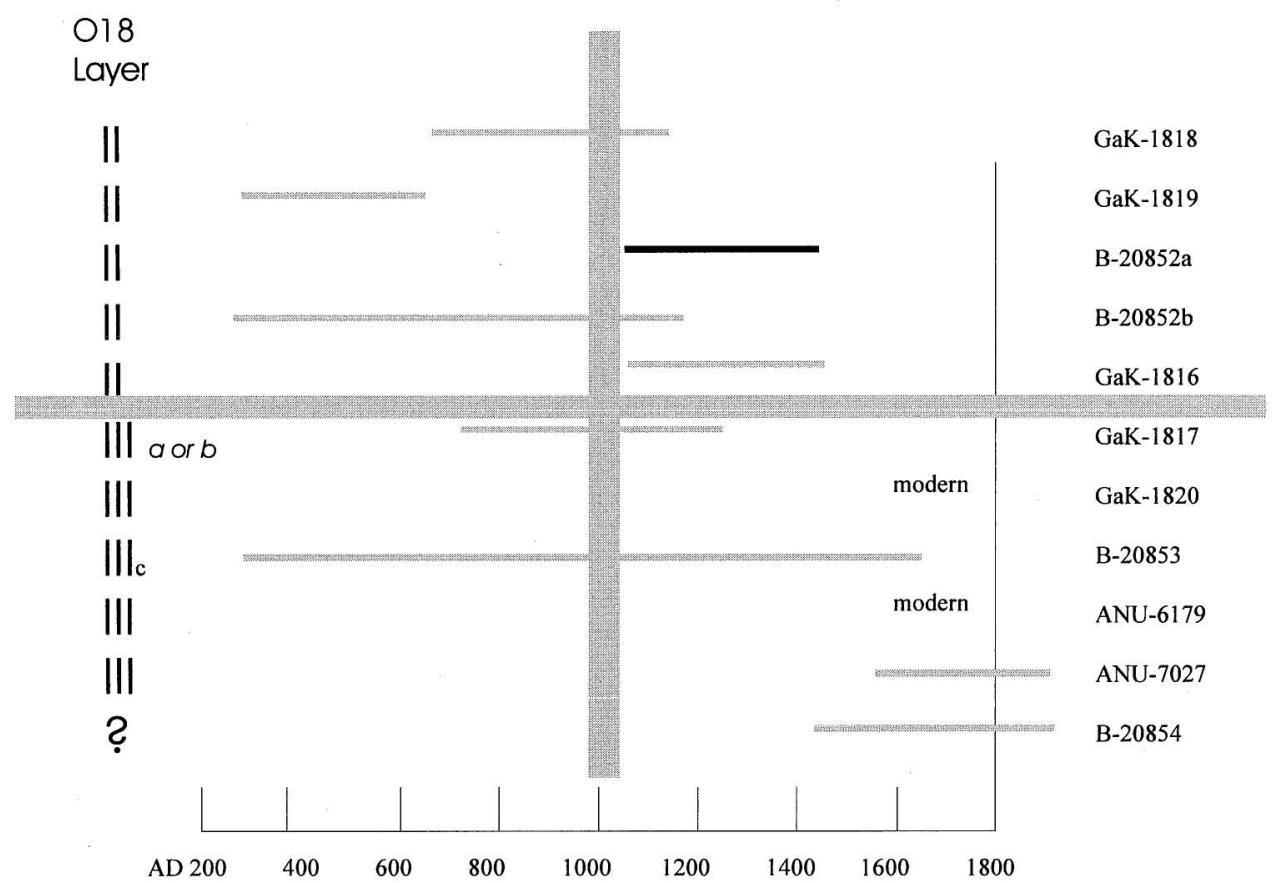

Fig. 6. Evaluated radiocarbon dates for the Bellows Dune site, set 2. The black line represents an acceptable date, the gray lines represent dates rejected by all negative criteria.

date or the date of old wood. ${ }^{12} \mathrm{GaK}-1818$ is scatter in a pit fill that apparently includes secondary material (including human bones). The pit from which the dating sample was obtained (Feature 5) intruded from L. II through L. III and thus probably contains some charcoal from this earlier occupation. For this and other reasons (see Table 1) this is not a very satisfactory date, but passes the minimum criteria defined above. GaK-1816 provides a reasonable date, and comes from a feature that was probably a fire pit. This would be one of the best dates in the entire set, if, unfortunately, the stratigraphic location of the feature were not in question. As described above, this has been tentatively assigned to L. II, but it is possible that it was associated with L. III.

The two new determinations for samples from L. II were taken from the same provenience, but separated into charcoal and kukui nut shell (see Table 1). The charcoal date (B-20852a) passes the minimum criteria, and provides a reasonable date range of A.D. 1028-1441. The companion kukui date (B-20852b) barely overlaps the charcoal date, but has a range too broad to be useful. Kukui nut shell is readily carried by stream and flood water and also preserves very well under most archaeological conditions. The shell is often brought into sites as secondary deposition. In cases where it is found in a distinctly cultural context (that is, clearly deposited by human action), it may still be considerably older than the collection event, preserved under natural conditions. However, it is almost certain that the kukui tree is a Polynesian introduction (Athens 1997), so dates on shells at least speak to the Polynesian presence in a general area (disregarding problems of natural spread within the islands). Thus the extended range of the date is not very 
informative, but is at least not inconsistent with expectations for occupation of the region.

In sum, if the stratigraphically acceptable GaK dates are used the following argument can be made: there is one sample (GaK-1817) that indicates an occupation of L. III in the A.D. 700-1200 range and three samples (GaK-1816, GaK1818, and B-20852a) that place L. II in the A.D. 700-1450 range. If the upper range of $\mathrm{GaK}-1818$ is used to eliminate this overlap, the ranges could be placed at A.D. 700-1100 for L. III and at A.D. 1100-1450 for L. II. However, if all GaK dates are deleted, we are left with a single date for L. II, A.D. 1028-1441 (B-20852a). If the most conservative analysis is taken, eliminating the use of ranges, then L. III predates A.D. 1000 and L.II post-dates A.D. 1000

\section{Radiocarbon Dates from the Vicinity of Bellows $\mathrm{O} 18$}

A number of radiocarbon dates have come from deposits near the O18 dune and from further inland along Puhā Stream (Tables 2 and 3; also see Fig. 2). None are from locations that can be stratigraphically tied to the original O18 layers. Two of the dates are deposits at the stream cut south of the dune (Site 4852-2) and seven are from a locale immediately inland of the dune (Site 4853-1). The earliest of these dates (B-29753) has a range of A.D. 884-1382, overlapping the proposed range from $\mathrm{O} 18 \mathrm{~L}$. III, but not predating it.

Additional dates have been obtained from deposits at Sites 4851-1, 4851-3, 4853-2, and 4853-5, all back from the coastal dunes (see Table 2 for dates and references). ${ }^{13}$ There is one early date in this set, A.D. 378-661 (B-25783), but it comes from stratigraphically contemporary deposits that also include two dates from the A.D. 1400 s to modern (B-25784 and B-31519). ${ }^{14}$ In the excavation reports for work in this area, it is noted (Shun 1993:47), that "... the wide differences in ages for charcoal samples from apparently similar stratigraphic contexts is problematic...." "Old wood" is the most likely explanation for this conflict. Lack of wood identification of the charcoal samples precludes an evaluation. The earliest date following B-27583 is B-31518 (A.D. 449-975), from unidentified scatter charcoal, derived from a provenience without significant cultural material.

All of the dates that come from identified carbonized wood (see Table 3) are in the A.D. 1200 range or later, and the wood is composed of only shrubby, shortlived, native species.

\section{ARTIFACTS AND THE AGE OF BELLOWS OI 8}

Given the original problems with radiocarbon dating at Bellows O18, the excavators made it clear that the artifacts provided a more "reliable" argument for an early occupation of the site. Adze and fishhook typology, along with the presence of a few unusual artifacts, particularly a coconut shell grater, are central to their argument. In general, the argument is that the forms (and in some cases, materials) occurring in this assemblage are not usually found in demonstrably later assemblages. They are seen as part of a complex found in "early" sites on the island of Hawai'i (H1 and H8), and as having affinities with early Marquesan types (Kirch 1985:71; Pearson et al. 1971). At the same time it is noted that the artifact complex indicates an "incipient stage in the development of Hawaiian culture" 
Table 2. Vicinity of the Bellows Dune Site (Oi 8), Radiocarbon Dates by Site

\begin{tabular}{|c|c|c|c|c|c|c|c|c|c|}
\hline $\begin{array}{l}\text { SITE AND } \\
\text { RADIOCARBON } \\
\text { NO. }\end{array}$ & $\begin{array}{l}\text { EXCAVATION } \\
\text { UNIT }\end{array}$ & $\begin{array}{l}\text { COLLECTION } \\
\text { UNIT }\end{array}$ & $\begin{array}{l}\text { QUANTITY } \\
\text { (gm) }\end{array}$ & MATERIAL & $\begin{array}{c}\text { MEASURED }{ }^{14} \mathrm{C} \\
\text { AGE (B.P.) }\end{array}$ & $\begin{array}{l}{ }^{13} \mathrm{C} /{ }^{12} \mathrm{C} \\
\text { RATIO } \% 0^{a}\end{array}$ & $\begin{array}{l}\text { CONVENTIONAL } \\
\text { AGE (B.P.) }\end{array}$ & $\begin{array}{l}\text { CALIBRATED } \\
\text { AGE A.D. } 2 ?^{b}\end{array}$ & REFS. \\
\hline \multicolumn{10}{|l|}{ Site $4851-1$} \\
\hline B-111023 & TR-4, Fe 3 & Fire pit & 0.34 & $\begin{array}{l}\text { cf. Rauvolfia } \\
\text { sandwicensis }\end{array}$ & - & -26.9 & $310 \pm 40$ & $1470-1950$ & (7) \\
\hline B-111024 & TR-4, Fe 2 & Fire pit & 0.36 & $\begin{array}{l}\text { Charcoal (Sida cf. } \\
\text { fallax) }\end{array}$ & - & -26.8 & $140 \pm 60$ & $1600-1950$ & (7) \\
\hline B-111025 & TR-4, Fe 1 & $\begin{array}{l}\text { Basalt flake } \\
\text { concentration }\end{array}$ & 0.31 & $\begin{array}{l}\text { Charcoal (Sida cf. } \\
\text { fallax) }\end{array}$ & - & -24.2 & $540 \pm 50$ & $1290-1450$ & (7) \\
\hline \multicolumn{10}{|l|}{ Site $4852-2$} \\
\hline B-29752 & $\begin{array}{l}\text { N. Wall, VIII, } \\
\text { top }\end{array}$ & Scatter? Pit? & $?$ & $\begin{array}{l}\text { Charcoal- } \\
\text { unidentified }\end{array}$ & $190 \pm 50$ & NA & $150 \pm 50$ & $1657-1955$ & (1) \\
\hline B-29753 & $\begin{array}{l}\text { E. Wall, VIII, } \\
\text { bottom }\end{array}$ & Scatter? & 0.4 & $\begin{array}{l}\text { Charcoal- } \\
\text { unidentified }\end{array}$ & $840 \pm 140$ & -27.8 & $905 \pm 135$ & $884-1382$ & $(1,6)$ \\
\hline \multicolumn{10}{|l|}{ Site $4853-1$} \\
\hline I-16652 & SqI14, Zone 1 & Hearth & ? & $\begin{array}{l}\text { Charcoal- } \\
\text { unidentified }\end{array}$ & $?$ & -26 & $270 \pm 80$ & $1448-1954$ & $(2)$ \\
\hline I-16654 & $\begin{array}{l}\text { 19, H10, } \\
\text { Zone } 1\end{array}$ & Earth oven & $?$ & $\begin{array}{l}\text { Charcoal- } \\
\text { unidentified }\end{array}$ & $?$ & -18.7 & $240 \pm 110$ & $1441-1955$ & (2) \\
\hline I-16688 & $\mathrm{H} 8$ & Hearth & $?$ & $\begin{array}{l}\text { Charcoal- } \\
\text { unidentified }\end{array}$ & $?$ & -29 & $230 \pm 80$ & $1477-1955$ & (2) \\
\hline I-16734 & H9 & Scatter & $?$ & $\begin{array}{l}\text { Waterlogged } \\
\text { wood frags. } \\
\text { unidentified }\end{array}$ & $?$ & $?$ & $770 \pm 80$ & $1051-1393$ & (2) \\
\hline B-16708 & TU19, L. II & $?$ & $?$ & ? & $101.6 \oplus 3.5 \% \mathrm{M}$ & -23.58 & $101.3 \pm 3.5 \% \mathrm{M}$ & Modern & (3) \\
\hline B-101871 & $\mathrm{BT} 1, \mathrm{Fe} 9$ & Pit & 0.6 & $\begin{array}{l}\text { Charcoal } \\
\text { (cf. Osteomeles } \\
\text { anthyllidifolia) }\end{array}$ & $720 \pm 40$ & -25.3 & $720 \pm 40$ & $1243-1380$ & (4) \\
\hline B-101872 & BT $23, \mathrm{Fe} 10$ & Pit & 0.3 & $\begin{array}{l}\text { Charcoal } \\
\text { (cf. Osteomeles } \\
\text { anthyllidifolia) }\end{array}$ & $670 \pm 40$ & -24.7 & $680 \pm 40$ & $1277-1396$ & (4) \\
\hline
\end{tabular}

(Continues) 
Table 2. (Continued)

\begin{tabular}{|c|c|c|c|c|c|c|c|c|c|}
\hline $\begin{array}{l}\text { SITE AND } \\
\text { RADIOCARBON } \\
\text { NO. }\end{array}$ & $\begin{array}{l}\text { EXCAVATION } \\
\text { UNIT }\end{array}$ & $\begin{array}{l}\text { COLLECTION } \\
\text { UNIT }\end{array}$ & $\begin{array}{l}\text { QUANTITY } \\
\text { (gm) }\end{array}$ & MATERIAL & $\begin{array}{c}\text { MEASURED }{ }^{14} \mathrm{C} \\
\text { AGE (B.P.) }\end{array}$ & $\begin{array}{l}{ }^{13} \mathrm{C} /{ }^{12} \mathrm{C} \\
\text { RAtio \%o }\end{array}$ & $\begin{array}{l}\text { CONVENTIONAL } \\
\text { AGE (B.P.) }\end{array}$ & $\begin{array}{l}\text { CALIBRATED } \\
\text { AGE A.D. 2? }\end{array}$ & REFS. \\
\hline \multicolumn{10}{|l|}{ Site $4853-2$} \\
\hline B-25783 & inland deposit & $\begin{array}{l}\text { Fire pit, bottom } \\
\text { of deposit }\end{array}$ & $?$ & $\begin{array}{l}\text { Charcoal- } \\
\text { unidentified }\end{array}$ & $1340 \pm 80$ & -12.8 & $1540 \pm 80$ & $378-661$ & (5) \\
\hline B-25784 & inland deposit & $\begin{array}{l}\text { Post mold, top } \\
\text { of deposit }\end{array}$ & $?$ & $\begin{array}{l}\text { Charcoal- } \\
\text { unidentified }\end{array}$ & $250 \pm 80$ & -18.2 & $360 \pm 80$ & $1420-1955$ & (5) \\
\hline B-31518 & $\begin{array}{l}\text { NW Quad, } \\
\text { L. VI }{ }^{c}\end{array}$ & Scatter & 3.0 & $\begin{array}{l}\text { Charcoal- } \\
\text { unidentified }\end{array}$ & $1350 \pm 130$ & -25.4 & $1340 \pm 130$ & $449-975$ & (5) \\
\hline B-31519 & $\begin{array}{l}\text { L IV, 125- } \\
\qquad 135 \mathrm{cmbd}\end{array}$ & Scatter & 10.1 & $\begin{array}{l}\text { Charcoal- } \\
\text { unidentified }\end{array}$ & $330 \pm 60$ & -22.1 & $380 \pm 60$ & $1439-1643$ & (5) \\
\hline \multicolumn{10}{|l|}{ Site 4853-5 } \\
\hline B-101868 & BT1, Fe 3 & Pit & 0.09 & $\begin{array}{l}\text { Charcoal (cf. Sida } \\
\text { fallax) }\end{array}$ & $210 \pm 40$ & -24.2 & $220 \pm 40$ & $1641-1954$ & (4) \\
\hline B-101869 & BT5, Fe 6 & Pit & 0.07 & $\begin{array}{l}\text { Charcoal } \\
\quad \text { (Chamaesyce sp.) }\end{array}$ & $30 \pm 60$ & -12.9 & $230 \pm 60$ & $1515-1954$ & (4) \\
\hline B-101870 & P1, L.II & Scatter & 0.19 & $\begin{array}{l}\text { Charcoal } \\
\text { (Chenopodium } \\
\text { oahuense) }\end{array}$ & $130 \pm 60$ & -22.5 & $170 \pm 60$ & 1644-1955 & (4) \\
\hline B-101873 & BT13, Fe16 & Pit & 0.45 & $\begin{array}{l}\text { Charcoal (Dodonea } \\
\text { viscosa) }\end{array}$ & $270 \pm 40$ & -21.8 & $320 \pm 40$ & $1470-1660$ & (4) \\
\hline B-111022 & TR-5, Fe 1 & Earth oven & 0.50 & $\begin{array}{l}\text { Charcoal (cf. Sida } \\
\text { fallax) }\end{array}$ & - & -27.5 & $150 \pm 40$ & $1480-1950$ & (7) \\
\hline
\end{tabular}

References: (1) Miller 1991:12; (2) Rolett 1992, table 1; (3) Hurlbett and Haun 1987; (4) Addison 1997; (5) Shun 1993, table 4 (and Shun, pers. comm. Dec. 29, 1992); (6) T. Dye (pers. comm. 1997) correction of data in Miller (1991) based on information obtained from Beta Analytic; (7) Dye 1998.

Note. For a detailed review of dates from the vicinity of Bellows Dune, see Dye in press.

${ }^{\mathrm{a}} \mathrm{NA}=$ not available.

${ }^{b}$ Note that these dates are calibrated or recalibrated from the original published sources with CALIB 3.0 (Stuiver and Reimer 1993).

${ }^{\mathrm{c}}$ Sample was from an alluvial deposit and probably not in situ charcoal (Shun 1993:47-50). 
Table 3. The Vicinity of the Bellows Dune Site (Oi 8), Radiocarbon Dates Ordered by Date of Early End of Age Range

\begin{tabular}{|c|c|c|c|c|}
\hline $\begin{array}{l}\text { RADIOCARBON } \\
\text { NO. }\end{array}$ & $\begin{array}{c}\text { SITE AND } \\
\text { EXCAVATION UNIT }\end{array}$ & $\begin{array}{l}\text { COLLECTION } \\
\text { UNIT }\end{array}$ & MATERIAL & $\begin{array}{l}\text { CALIBRATED } \\
\text { AGE A.D., 2? }\end{array}$ \\
\hline B-16708 & $\begin{array}{l}\text { Site } 4853-1 \text {; TU19, } \\
\text { L. II }\end{array}$ & $?$ & $?$ & Modern \\
\hline B-29752 & $\begin{array}{l}\text { Site } 4852-2 \text {; N. } \\
\text { Wall, VIII, top }\end{array}$ & Scatter? Pit? & Charcoal-unidentified & $1657-1955$ \\
\hline B-101870 & $\begin{array}{l}\text { Site 4853-5; P1, } \\
\text { L.II }\end{array}$ & Scatter & $\begin{array}{l}\text { Charcoal (Chenopodium } \\
\text { oahuense) }\end{array}$ & $1644-1955$ \\
\hline B-101868 & $\begin{array}{l}\text { Site } 4853-5 \text {; BT1, } \\
\quad \text { Fe } 3\end{array}$ & Pit & Charcoal (cf. Sida fallax) & $1641-1954$ \\
\hline B-111024 & $\begin{array}{l}\text { Site } 4851-1 \text {; TR-4, } \\
\quad \text { Fe } 2\end{array}$ & Fire pit & Charcoal (Sida cf. fallax) & $1600-1950$ \\
\hline B-101869 & $\begin{array}{l}\text { Site } 4853-5 \text {; BT5, } \\
\quad \text { Fe } 6\end{array}$ & Pit & Charcoal (Chamaesyce sp.) & $1515-1954$ \\
\hline B-111022 & $\begin{array}{l}\text { Site 4853-5; TR-5, } \\
\quad \text { Fe } 1\end{array}$ & Earth oven & Charcoal (cf. Sida fallax) & $1480-1950$ \\
\hline I-16688 & Site $4853-1 ; \mathrm{H} 8$ & Hearth & Charcoal-unidentified & $1477-1955$ \\
\hline B-111023 & $\begin{array}{l}\text { Site } 4851-1 \text {; TR-4, } \\
\quad \text { Fe } 3\end{array}$ & Fire pit & cf. Rauvolfia sandwicensis & $1470-1950$ \\
\hline B-101873 & $\begin{array}{l}\text { Site 4853-5; BT13, } \\
\text { Fe16 }\end{array}$ & Pit & $\begin{array}{l}\text { Charcoal (Dodonea } \\
\text { viscosa) }\end{array}$ & $1470-1660$ \\
\hline I-16652 & $\begin{array}{l}\text { Site } 4853-1 ; \text { SqI14, } \\
\quad \text { Zone } 1\end{array}$ & Hearth & Charcoal-unidentified & $1448-1954$ \\
\hline I-16654 & $\begin{array}{l}\text { Site } 4853-1 ; 19, \\
\quad \text { H10, Zone } 1\end{array}$ & Earth oven & Charcoal-unidentified & $1441-1955$ \\
\hline B-31519 & $\begin{array}{l}\text { Site 4853-2; L IV, } \\
\quad 125-135 \mathrm{cmbd}\end{array}$ & Scatter & Charcoal-unidentified & $1439-1643$ \\
\hline B-25784 & $\begin{array}{l}\text { Site } 4853-2 \text {; inland } \\
\text { deposit }\end{array}$ & $\begin{array}{l}\text { Post mold, top } \\
\text { of deposit }\end{array}$ & Charcoal-unidentified & $1420-1955$ \\
\hline B-111025 & $\begin{array}{l}\text { Site } 4851-1 \text {; TR-4, } \\
\quad \text { Fe } 1\end{array}$ & $\begin{array}{l}\text { Basalt flake } \\
\text { concentration }\end{array}$ & Charcoal (Sida cf. fallax) & $1290-1450$ \\
\hline B-101872 & $\begin{array}{l}\text { Site } 4853-1 ; \mathrm{BT} \\
\quad 23, \mathrm{Fe} 10\end{array}$ & Pit & $\begin{array}{l}\text { Charcoal (cf. Osteomeles } \\
\text { anthyllidifolia) }\end{array}$ & $1277-1396$ \\
\hline B-101871 & $\begin{array}{l}\text { Site 4853-1; BT 1, } \\
\quad \text { Fe } 9\end{array}$ & Pit & $\begin{array}{l}\text { Charcoal (cf. Osteomeles } \\
\text { anthyllidifolia) }\end{array}$ & $1243-1380$ \\
\hline I-16734 & Site 4853-1; H9 & Scatter & $\begin{array}{l}\text { Waterlogged wood frags- } \\
\text { unidentified }\end{array}$ & $1051-1393$ \\
\hline B-29753 & $\begin{array}{l}\text { Site } 4852-2 \text {; E. } \\
\text { Wall, VIII, } \\
\text { bottom }\end{array}$ & Scatter? & Charcoal-unidentified & 0884-1382 \\
\hline B-31518 & $\begin{array}{l}\text { Site 4853-2; NW } \\
\text { Quad, L. VI }\end{array}$ & Scatter & Charcoal-unidentified & $0449-0975$ \\
\hline B-25783 & $\begin{array}{l}\text { Site } 4853-2 \text {; inland } \\
\text { deposit }\end{array}$ & $\begin{array}{l}\text { Fire pit, bottom } \\
\text { of deposit }\end{array}$ & Charcoal-unidentified & $0378-0661$ \\
\hline
\end{tabular}

(Pearson et al. 1971:232), and that this is not a "first" settlement site in the islands (Kirch $1985: 298)$.

These conclusions may very well be correct, but there are problems with the artifact-based chronology. First, there are very few temporally diagnostic artifacts in the assemblage. Further, the artifacts are much poorer indicators of chronology 
than put forward in the original O18 analysis. From the 1967 excavations, there were 18 fishhooks and four adzes and adze preforms. The use of pearl shell and simple drilling formed much of the basis for an argument of early fishhooks, but at the same time "the typology is somewhat inconclusive, although not contrary to that of material and manufacture technique (which suggest early occupation)" (Pearson et al. 1971:231).

The adzes "suggest a period prior to the development of the usual, quadrangular, tanged Hawaiian adz" (Pearson et al. 1971:231). There are two complete adzes and two preforms from the 1967 excavations (Pearson et al. 1971:225), but only one of these, a preform with a trapezoidal cross section, was from L. III. A reverse triangular adze was found in Layer II, associated with Burial 2. The provenience of the other complete adze (with a trapezoidal cross section) is not given, and the second preform has an indeterminate cross section (Pearson et al. 1971:225). No adzes were found in situ from the 1975 excavations (Cordy and Tuggle 1976:220). One reverse triangular preform was found in the main cultural deposit in the bridge profile (Miller 1991:12), but no information is given that would allow it to be associated with either of the radiocarbon dates from the deposit.

The small number of adzes from O18 provides a less than satisfactory foundation for such an important argument, and the argument is further weakened when adze temporal typology is considered critically. Typology begins with manufacturing material and methods, which then have an effect on local variation in type distribution (McCoy et al. 1993). For the Bellows and nearby Kualoa area, it has been argued that the adzes are manufactured from local dike materials and that the reverse triangular form depends largely on the shape of the dike stone (Gunness 1987). Demonstrating the temporal component of form is much more difficult. Cleghorn's analysis of dated adzes (1992) shows little relationship between chronology and type. Chronological inferences based on artifacts have proved irksome in Hawaiian archaeology (see, for example, Dye 1992), and problems of persistence of supposedly early styles appear in various cases.

Finally, one other possible characteristic of an early component needs to be considered - that is the presence of bird bone and turtle bone in the midden (Dye and Steadman 1990; Kirch 1982, $1985: 292$ ). Although none of the O18 excavation reports include detailed midden data, they indicate a generally low midden density and the virtual absence of bird bones (Cordy and Tuggle 1976:220-221; Pearson et al. $1971: 230)$.

A strong argument against typological chronology and affinities is made by Kirch $(1974: 118)$ in his assessment of early east Polynesian assemblages, indicating that there is inadequate knowledge of early sites throughout eastern Polynesia to allow solid comparisons, and that there may never have been the degree of differentiation in early assemblages of specific regional identification. This situation has improved little since the 1974 article was written and the problem is echoed in a recent assessment of early sites in east Polynesia (Cachola-Abad 1993) that provides a substantial argument regarding the inadequacies of comparing early assemblages.

Perhaps a more important component of the Cachola-Abad study (1993) is a re-evaluation of Hawaiian traditions regarding long-distance voyaging that supports the historical validity of multiple round-trip voyages to Hawai'i over a long 
period of time, ${ }^{15}$ but also argues that these voyages involved contact with more than just one other Polynesian island group. Of the many implications of this position, one of the important ones for the consideration of Bellows dating is that sites showing material traits similar to those found elsewhere in Polynesia do not necessarily represent either early or pristine colonizers, and further that these sites will not necessarily be similar to one another.

The Bellows assemblage is unquestionably unusual, ${ }^{16}$ and may in fact eventually prove to be quite early in the Hawaiian sequence, but it is difficult to make a strong argument at the present time. However, the artifacts do not solve the Bellows dating problem, and we return to the point that absolute age determinations are necessary to unravel the artifactual problems.

\section{DISCUSSION: BELLOWS AND THE ISSUE OF PRE-A.D. 600 SITES IN HAWAI'I}

Several recent papers are concerned with the issue of the date of Hawaiian colonization. Coring data from O'ahu are consistently pointing to a post-A.D. 800 date for this event (Athens 1997; Athens et al. 1999). ${ }^{17}$ A reanalysis of Hawaiian traditions and a review of astronomical events referenced in these traditions suggest an A.D. 700-800 date (Masse and Tuggle 1998). One paper that argues for a pre-A.D. 600 colonization is that of Graves and Addison (1995), who suggest that conclusions can be gleaned from some of the early dates rejected by Spriggs and Anderson (1993).

Graves and Addison (1995) develop a model for evaluation of radiocarbon data patterns relevant to the issue of island colonization. They argue that a successful colonization has three phases: discovery, colonization itself, and establishment (that is, successful, long-term occupation). They identify four models by which settlement could have taken place based on the time-lag between each phase, and argue that the Spriggs and Anderson post-A.D. 600 cluster of reliable early dates represents the establishment period, which could also incorporate discovery and colonization if these events occurred in rapid succession. However, they suggest that there are radiocarbon dates that indicate discovery and colonization occurred well before establishment, dates that support a model of discovery and a "protracted phase of colonization" prior to A.D. 500 (Graves and Addison 1995:394).

The argument is based on a re-evaluation of dates, many of which were rejected by Spriggs and Anderson (1993) as unreliable. They agree with Spriggs and Anderson (1993) that dates have to meet these criteria: (1) are not associated with laboratory error; (2) are on wood charcoal; and (3) have a range of less than 900 years at 2 -sigma. However, they disagree with the argument that dates can be rejected on the basis of questionable provenience. They evaluate 26 pre-A.D. 1000 range dates from the island of Hawai' $i$ and 26 from the island of O'ahu.

Of 26 dates from Hawai'i, 19 postdate A.D. 600 and "confirm the conclusion offered by Spriggs and Anderson (1993) regarding the timing of settlement in Hawai'i." However, these show a wide geographic range (including two from inland areas), that would seem to point to "establishment of the Polynesian population in various parts of the island during the late first millennium A.D." For O'ahu, "eleven ... cluster in the interval A.D. 600 to A.D. 1000 ... and are congruent with [the] analysis of the Hawai'i Island radiocarbon dates..." (Graves and Addison $1995: 393$ ). 
It is not clear how 19 Hawai' $i$ Island dates, which are context-free, demonstrate establishment. Even assuming these dates are reliable, this represents 19 events over a total radiocarbon date span of 779 years (A.D. 610-1389: Graves and Addison, 1995, table 3 and fig. 4), with the range of 16 of the 19 dates extending beyond the A.D. 1000 boundary, in 9 of the 16 by 100 years or more. In other words the potential scatter of events in these dates could easily accommodate well-separated discovery and colonization dates, and establishment after A.D. 1000. For $\mathrm{O}^{\prime} \mathrm{ahu}$, six of the eleven dates extend into the post-A.D. 1000 period, and the same argument applies as with the Hawai'i Island dates.

Although Graves and Addison (1995) agree that the accepted dates by Spriggs and Anderson could represent discovery, colonization, and establishment (and we would argue in all of the models, not just one or two), they suggest that other dates indicate support of a model of pre-A.D. 600 discovery and colonization. For Hawai' $i$ Island the argument rests on three dates (19 of the 26 dates are placed in the post-A.D. 600 range and two are rejected as anomalous). ${ }^{18}$ Here Graves and Addison (1995:392) consider two hypotheses to account for these three dates: that they represent an "earlier component of settlement" or, as others have suggested, that they are dates on old wood. They then comment:

Unfortunately, archaeologists in Hawai'i still do not routinely subject their charcoal samples for radiocarbon dating to taxonomic identification. ${ }^{19}$ Thus we cannot be certain that there is no old wood represented in these assemblages. Given this problem and the relatively few dates for this time interval from Hawai'i Island, it is difficult to evaluate either hypothesis.

It may be more than difficult, perhaps impossible. ${ }^{20}$ In the absence of other supporting information (such as a tight stratigraphic sequence of consistent dates) this means that the data should be thrown out, exactly as Spriggs and Anderson have indicated, so we are left with no reliable early dates.

For O'ahu there are nine dates that fall between A.D. 200 and 600. These dates are unacceptable according to Spriggs and Anderson, but Graves and Addison (1995:394) argue that "None the less, these dates are from sites with nearly the same geographic distribution on O'ahu as the post-A.D. 600 dates (i.e., from both windward and leeward districts)."

The alternative old wood hypothesis is not repeated here by Graves and Addison, but there is no reason why it is not applicable (see, for example, Athens and Ward 1997). If that is the case there is a set of data that has to be rejected, again as Spriggs and Anderson argued. However, regarding both sets of dates, they conclude (Graves and Addison 1995:394):

... we argue that the hypothesis which invokes the dating of old wood or driftwood to account for this set of dates does not seem consistent with their temporal clustering and geographic distribution. No one has identified formation processes which would account for the similar temporal pattern on two different islands (and their occurrence at a variety of sites on $\left.\mathrm{O}^{\prime} \mathrm{ahu}\right)$.

There are several points to be made here. The first is that the temporal "clustering" is questionable. Each set of dates in the pre-A.D. 600 range is quite different (compare Graves and Addison 1995, figs. 4 and 6). Within each set the patterning depends on how the dates are arranged: by midpoint, or by one of the two end points; and further, how overlap is treated. As far as identifying natural processes to account for whatever patterning there might be, while we know of no explicit 
case of this, ${ }^{21}$ the old wood and driftwood models clearly contain the flexibility to account for the dates indicated, including the four anomalous dates that Graves and Addison reject. Along the coastline and in some leeward environments in general, old wood and driftwood would preserve well and thus be of any age preceding the date of their burning. In the interior of the windward side, dead wood might not survive long, but wood cut and burned from old trees (as a part of forest clearance) could be of considerable age.

Building natural formation models more elaborate than this to account for 11 dates, however, hardly seems worth the effort, and there are other considerations that make it a pointless exercise. First, for archaeological specimens of questionable context there is the issue of whether the burned wood is cultural or natural. This particularly applies to the island of Hawai' $i$ where natural fires are common, but may not apply to O'ahu where natural fires in the geologically recent era may be rare or nonexistent (Athens and Ward 1993, 1997). Further, all of the evaluations of dating depend on the identification of the dated specimen as wood charcoal. Given some of the ambiguities of sample submission one might question the wood part, but more importantly there is good reason to question the charcoal part. In the absence of detailed study of specimens, there is no assurance that samples submitted for dating are not wood blackened by anaerobic processes rather than by burning (see Athens and Ward 1997:39), which of course raises the question as to whether such a specimen is cultural or natural.

It is of unquestioned value and of conceptual necessity to build models by which to understand data, but how close is this to a circular argument if the data have not been demonstrated as reliable? ${ }^{22}$ We suggest that most of the 11 dates in question are unreliable for the reasons identified in Spriggs and Anderson (1993), and will also accept the argument by Graves and Addison that the absence of wood identification (and we would add absence of evidence for cultural carbonization) means that alternative hypotheses for their origin cannot be readily evaluated.

We thus need additional dates that have credibility. ${ }^{23}$ Further, additional types of data can be used to evaluate the age of colonization (see, for example, Masse and Tuggle 1998). In this regard, Graves and Addison (1995:389) appear to accept data from wetland coring from the Cook Islands as evidence that addresses the age of discovery and colonization. ${ }^{24}$ Given that, the extensive coring data from O'ahu clearly indicate a date of around A.D. 800 for discovery and colonization (Athens 1997; Athens and Ward 1993; Athens et al. 1999).

Finally, the age of discovery and colonization might be considered in relation to the age of establishment. Establishment is defined by Graves and Addison (1995:385) as "occupation of an island by a population of sufficient size (i.e., one that has passed the threshold at which catastrophic accidents or reproductive bottleneck would be likely to affect its long-term viability)." We suggest that the pattern of cumulative radiocarbon dates (Dye and Komori 1992) is an appropriate way to determine the date of establishment. The point at which the Dye-Komori curve begins an upward curve (upward asymptote) suggests that establishment can be identified around A.D. 1150.25

\section{CONCLUSIONS AND IMPLICATIONS}

The Bellows O18 dune site remains poorly dated. The most supportable conclusion is that L. III pre-dates A.D. 1000, and that L. II post-dates A.D. 1000. If less 
stringent criteria are used, the lowest component, L. III, might date within the range of A.D. 700-1100, but this is based on one questionable GaK radiocarbon determination, from charcoal probably associated with L. IIIa (or possibly with L. IIIb). There are no dates associated with L. IIIc. This date is considerably later than the A.D. 300-600 range that has been generally accepted for nearly three decades. At the same time, it falls into a colonization date range of A.D. 800-900 that is suggested by other data (e.g., Athens et al. 1999). This means that the artifactual evidence that this component represents "an incipient stage in the development of Hawaiian culture" (Pearson et al. 1971:232) may well eventually prove valid. The artifactual argument will ultimately depend on the process of understanding the history of east Polynesian settlement and culture history as a whole, a process that is proving to be a long-term affair indeed.

In Kirch's (1985) review of Hawaiian archaeology Bellows O18 and the Pu'u Ali'i dune site (H1) on the island of Hawai'i provided the only two cases for early settlement sites in the islands dating to the A.D. 300-600 Colonization period. A re-evaluation of the dates from Pu'u Ali'i (Dye 1992) has resulted in the rejection of the early date of that site in favor of a fifteenth-century occupation age for its earliest component. The present re-evaluation of the dates from Bellows O18 suggests that this site's lowest component also dates well after the A.D. 300-600 range. In the absence of other good examples of well-dated occupations, there is no strong evidence for the Colonization period, as defined. For early sites, then, it is necessary to fall back onto those sites that date in the early range of the Developmental period (A.D. 600-1100, Kirch 1985:302).

The radiocarbon determination for L. II indicates a date range of A.D. 11001450 (the specificity depending on acceptance or rejection of GaK dates), with L. IIa undated. This means two things. First, the typologically "early" artifacts found in this layer are pushed into a time period where they cannot be explained by association with early settlement, and instead speak to issues of persistence, locally constrained manufacturing form, or long-term history of Polynesian voyaging contact (cf. Cachola-Abad 1993). Second, this provides a later date than previously proposed for the child burial with the lei niho palaoa, and thus does not provide evidence for the early development of a chiefly symbol and associated status differentiation (see Kirch $1985: 74,303$ ). ${ }^{26}$

In the nonexperimental sciences there is always a problem of having a clear understanding of what is to be explained. In the case of Hawai' $i$, explaining initial colonization in A.D. 800 is quite a different matter from explaining initial settlement at A.D. 100. Further, the larger context of Hawaiian settlement has now changed in that present evidence suggests that colonization of eastern Polynesia as a whole may be much later than previously argued (Rolett 1989; Spriggs and Anderson 1993). This obviously has important implications for how "early" artifact types in Hawai' $i$ are to be viewed. More importantly, if Polynesian dispersal and exploration did not occur in some linear form or occurred with long time lags between island settlement, then we may be looking at a very different process from what has been commonly envisioned (for additional discussion of this point, see Anderson 1996; Graves and Addison 1995; Kirch and Ellison 1994).

It is unknown if there are any intact $\mathrm{O} 18$ deposits remaining in the dune remnant at Bellows. ${ }^{27}$ But this is certainly one of the most important sites on O'ahu, and the professional attitude about the dune has always been to conserve it for 
"future research" when archaeological methods have improved. Methods have improved and it is time to recover whatever information may be left. A new millennium is here and the time for future research is now.

\section{ACKNOWLEDGMENTS}

We would like to thank the University of Hawai' $i$ for provision of a Research and Training Revolving Fund Award to Spriggs in 1986 for the project "Early Hawaiian Settlement in Windward O'ahu." For providing charcoal samples from the original O18 excavations, the Bishop Museum is thanked, particularly Toni Han, Elaine Jourdane, and Jama Duckworth-Williams. Appreciated for their help in 1986 are Ross Cordy, Ben Finney, Bion Griffin, Michael Graves, Rob Hommon, and Pat Kirch. Useful comments were received from participants at the 1991 conference of the Society for Hawaiian Archaeology, where a paper based on this research was presented. We wish to thank Tom Dye, Anne Garland, John Head, Holly McEldowney, Deborah Olszewski, Steve Robertson, and Ken Shun for information germane to the paper and we also very much appreciate the comments by Tim Denham, Tom Dye, Michael Graves, and Steve Athens on an early version of the paper.

\section{NOTES}

1. For example, Hunt and Holsen (1991:158) propose that the radiocarbon dates "might be suggestive of a human presence [in Hawai'i] as early as the first century A.D." Kirch $(1985: 298$, emphasis original) indicates that the earliest dated sites "do not appear to be the first settlement site[s] in the islands"; Tuggle (1979:189) suggests colonization "sometime prior to A.D. 400."

2. Ironically, as Graves and Addison (1995:380) point out, the "short chronology" returns to a position held by archaeologists in the early years of radiocarbon dating (e.g., Emory 1959). At the same time the long chronology is consistent with the nineteenth-century calculations of the date of Hawaiian settlement of around A.D. 500, based on genealogical traditions (Fornander 1969:2).

3. In 1986 Spriggs was concerned with the problem of O18 dating and obtained charcoal samples for radiocarbon dating from the Bishop Museum derived from the 1967 excavations. These results were presented and discussed at a conference (Spriggs 1991). Independently, Tuggle (1994, revised in 1997) reviewed the evidence for the chronology of O18. The present paper is a combination and updating of these two studies.

4. The designation O18 is the original Bishop Museum site number (Pearson et al. 1971). Subsequently a State of Hawai'i site number 80-15-511 was assigned to the area of O18, but also included the entire beach front of the Bellows area. Because the 511 refers to too large an area to be useful, a new State number has now been assigned to the area of the Bellows dune: 80-15-4852 (Tuggle 1997). To clearly identify this as the original Bellows site, this is identified as 4852 (Location O18) (Tuggle 1997). For practical purposes, O18 or Bellows O18 has become the historically identifiable site designation and is used in the present paper.

5. It is clear that this occurred as a part of sand-mining, probably by the military or by civilian construction contractors. The small remnant portion has continued to deteriorate from erosion, and has become heavily overgrown with trees, whose roots have probably done considerable damage to any remaining deposit.

6. An excellent summary of the early dates that is sympathetic to the long chronology is provided in Cordy (1996), but we do not agree with his acceptance of the pre-A.D. 700-800 dates, for reasons discussed in the main text of this paper.

7. Only cultural layers were given designations. L.I was a disturbed, recent cultural deposit.

8. One of us (Tuggle 1994, version of 1997), in a fit of despair, did in fact propose this.

9. Other approaches to more formal statistical analyses might also be attempted, e.g., Bayesian analysis (see Dye 1998, 1999).

10. It was originally suggested that the modern date of GaK-1820 may have resulted from contamination due to "exposure to the elements" (Pearson et al. 1971:230). It is not quite clear how exposure would cause contamination (although we might worry about the 1962 hydrogen bomb test at Johnston Island), but this presumably would not account for all three modern dates. 
11. Unfortunately, the site report is not consistent as to what type of feature this is. The radiocarbon table (Pearson et al. 1971, fig. 13) indicates that this is from a "fire pit" in square N9, L.IIIb, but does not provide a feature number. The plan view drawing of square N9 indicates GaK 1817 is associated with Feature 52 (Pearson et al. 1971, fig. 4) but no description of the feature is provided; the caption indicates that this is $\mathrm{L}$. IIIa. In the feature list Feature 52 is described as a "concentration of basalt flakes" and it is noted that GaK-1817 came from this feature (Pearson et al. 1971, table 2), and the feature list only notes that this is from L. III, without identifying whether this is IIIa or IIIb.

12. It has also been suggested that the older date from the upper layer may be due to displaced charcoal (Kirch 1974:114), but there is no source of early dated charcoal for such displacement.

13. The dates in Table 2 are from sites on the same side of Puhā Stream as O18. Another 15 radiocarbon dates have been derived from samples collected from sites on the opposite side of the stream, and generally inland (Site 4851). The earliest of these dates is A.D. 782-1178 (B-30891, Hammatt and Shideler 1989:58). None of the remaining 14 dates has a lower 2-sigma date range that is earlier than A.D. 1000 (see summary in Tuggle 1997, table 6). See Dye (2000) for a review of all of the radiocarbon dates from the vicinity of the Bellows site.

14. A second early date from this general area is B-31518, but it derives from material in secondary deposition in stream alluvium (Shun 1993:50). There is also the problem that this secondary material may be anaerobically blackened wood, not charcoal.

15. One of us (Tuggle 1979:189) took the position that multiple precontact migrations or voyages to Hawai' $i$ were unlikely, but has since rejected this stand (Masse and Tuggle 1998; Tuggle 1997).

16. For example, as far as we know there are only three other shell coconut graters in the artifact collection of the Bishop Museum (all from surface collections): from Kihei, Maui; Punalu'u, O'ahu; and Kahuku, O'ahu (catalogue numbers C1959, C6045, and C8286, respectively). This information is based on a search of Bishop Museum records by Spriggs.

17. The Athens et al. (1997) research on the 'Ewa Plain also involved the radiocarbon dating of bone of the Polynesian rat (Rattus exulans) as a non-site approach to dating Hawaiian colonization, following the lead of James et al. (1987). Subsequently, additional dates from Polynesian rat bone were obtained in another project (Dye 1999), producing a total of eight dates for rat on the 'Ewa Plain, none of which has a calibrated range that exceeds 1,100 years B.P.

18. In the case of the Hawai'i Island dates, the two early dates are considered anomalous because they do not overlap the later sequence. It is not made clear why these dates are not used in their model as evidence of the discovery phase of settlement.

19. If this means all archaeologists in Hawai' $i$ this statement is not true. Some individuals and organizations have been "routinely" having wood identified for about the last ten years (see, for example, McNeill 1989; Murakami 1993). At the same time, there are many recent projects for which wood identification is not conducted prior to radiocarbon dating-an inexcusable oversight - the necessity of which has been emphasized for several years (e.g., Hunt and Holsen 1991).

20. It would be possible only if someone should miraculously find a split remnant of the dated specimens so that wood identification could be conducted. Graves and Addison of course argue that at least a degree of hypothesis evaluation may be achieved through use of models, but as noted in our discussion the utility. of this seems very limited indeed.

21. However, Tuggle (1997) has proposed an interpretive protocol for dealing with early dates and the dating of early sites.

22. Much of the argumentation related to Graves and Addison (1995) concerns early dates, not early sites. We take the position that identification of an early settlement site will require the support of telling artifactual material as well as dates; unfortunately, as we argue here, and as others suggest (e.g., Cachola-Abad 1993), exactly what those artifactual data will prove to be is by no means clear.

23. The larger problem for Hawaiian archaeology is developing a form of argumentation for establishing the credibility of dates and for drawing chronological inferences pertinent to the types of sites and deposits or the area (see Dye 1998, and for comparison Shott 1992, and Smiley and Ahlstrom 1998).

24. As M. Graves points out (pers. comm.) these islands are much smaller than the main Hawaiian group, and environmental effects could be argued to show up much more quickly in pollen profiles than might be the case for Hawai'i.

25. The Dye-Komori (1992) curve was constructed from radiocarbon dates from all the islands. Subsequently, radiocarbon curves based on dates from specific regions (dating sets independent from that used by Dye and Komori) have shown the same shape curve, but with some variations in timing that match expectations for differences in regional settlement history (e.g., TomonariTuggle et al. 1999, figs. 18 and 19). 
26. In fact the association of this child (Burial 4) with L. II itself has always been in question, with a strong possibility that it is later than L. II. The excavators expressed a good deal of uncertainty about this, and in several places suggested that it is "intrusive into" L. II, that is, not originating in it, but above it (see, for example, Pearson et al., 1971, table 1, 214, 232).

27. It also might be possible to pursue additional dating of the material from previous excavations, if secure provenience could be assured and datable material found in collections. No shell, for example, has been dated from $\mathrm{O} 18$.

\section{REFERENCES}

Addison, D.

1997 Archaeological Subsurface Testing for the Removal of Pipeline Utilities under the Installation Restoration Program at Bellows Air Force Station, Waimanalo, Ko'olaupoko District, O'ahu, Hawai'i. Draft prepared for U.S. Army Corps of Engineers, Pacific Ocean Division, Ft. Shafter. Honolulu: International Archaeological Research Institute, Inc.

Anderson, A. J.

1996 Adaptive voyaging and subsistence strategies in the early settlement of East Polynesia, in Prehistoric Mongoloid Dispersals: pp. 359-373, ed. T. Akazawa and E.J.E. Szathmary. Oxford: Oxford University Press.

Athens, J. S.

1997 Hawaiian native lowland vegetation in prehistory, in Historical Ecology in the Pacific Islands: pp. 258-270, ed. P. V. Kirch and T. L. Hunt. New Haven: Yale University Press.

Athens, J. S., AND J. V. WARD

1993 Environmental change and prehistoric Polynesian settlement in Hawai'i. Asian Perspectives $32(2): 205-223$.

1997 The Maunawili core: Prehistoric inland expansion of settlement and agriculture, O'ahu, Hawai'i. Hawaiian Archaeology 6:37-51.

Athens, J. S., J. V. Ward, H. D. Tuggle, and D. R. Welch

1999 Environment, Vegetation Change, and Early Human Settlement on the 'Ewa Plain: A Cultural Resource Inventory of Naval Air Station, Barbers Point, O'ahu, Hawai'i, Part III: Paleoenvironmental Investigations. Report prepared for Pacific Division, Naval Facilities Engineering Command, U.S. Navy. Honolulu: International Archaeological Research Institute, Inc.

Cachola-Abad, C. K.

1993 Evaluating the orthodox dual settlement model for the Hawaiian Islands: An analysis of artifact distribution and Hawaiian oral traditions, in The Evolution and Organization of Prehistoric Society in Polynesia: pp. 13-32, ed. M. Graves and R. Green. New Zealand Archaeological Association Monograph No. 19.

Chun, M. N., ANd M. Spriggs

1987 New terms suggested for early Hawaiian history. Ka Wai Ola O Oha, Monthly Newspaper of the Office of Hawaiian Affairs, February, 4(2), p. 4. Honolulu.

Cleghorn, P. C.

1992 A Hawaiian adz sequence or just different kinds of adzes? New Zealand Journal of Archaeology $14: 129-149$.

CORDY, R.

1996 The rise and fall of the O'ahu Kingdom: A brief overview of O'ahu's history, in Oceanic Culture History: Essays in Honour of Roger Green: pp. 591-613, ed. J. M. Davidson, G. Irwin, B. F. Leach, A. Pawley, and D. Brown. New Zealand Journal of Archaeology Special Publication.

Cordy, R., And H. D. Tuggle

1976 Bellows, O'ahu, Hawaiian Islands; new work and new interpretations. Archaeology and Physical Anthropology in Oceania $11: 207-235$.

Dye, $T$.

1992 The South Point radiocarbon dates thirty years later. New Zealand Journal of Archaeology $14: 89-97$.

1998 Archaeological Services in Support of the Final Environmental Impact Statement for Proposed Expansion of Military Training and the Construction of Improvements to Existing Recreational 
Resources at Bellows Air Force Station, Waimanalo, Hawai 'i: Task 2: Archaeological Investigations for Specific Areas. Prepared for Department of the Navy, Pacific Division, Naval Facilities Engineering Command. Honolulu: International Archaeological Research Institute, Inc.

1999 A Bayesian Calibration of ${ }^{14}$ C Determinations from Two Sinkholes and a Surface Habitation Feature at Barbers Point, O'ahu. Prepared for Cultural Surveys Hawaii. Honolulu: International Archaeological Research Institute, Inc.

2000 Effects of ${ }^{14} \mathrm{C}$ sample selection in archaeology: An example from Hawai'i. Radiocarbon $42(2): 203-217$.

Dye, T., AND E. KoMORI

1992 A pre-censal population history of Hawai'i. New Zealand Journal of Archaeology 14:35-43.

Dye, T., and D. W. Steadman

1990 Polynesian ancestors and their animal world. American Scientist, May-June: 207-216.

EMORY, K. P.

1959 Radiocarbon dates from Hawaii. Journal of the Polynesian Society 68:240-241.

EMORY, K. P., AND Y. H. Sinoto

1969 Age of Sites in the South Point Area, Ka'u, Hawai'i. Pacific Anthropological Records 8. Honolulu: Bishop Museum.

FORNANDER, A.

1969 An Account of the Polynesian Race. Three volumes in one. Charles E. Tuttle, Rutland, Vermont. First published in 1878-1885.

Graves, M. W., AND D. J. AdDison

1995 The Polynesian settlement of the Hawaiian Archipelago: Integrating models and method in archaeological interpretation. World Archaeology 26:380-399.

GunNess, J. L.

1987 Archaeological investigations at Kualoa regional park, 1975-1985, an overview. M.A. thesis in Anthropology, University of Hawai'i.

Hall, E. O.

1839 Notes of a tour around Oahu. Hawaiian Spectator 2:94-112.

Hammatt, H. H., AND D. W. ShideleR

1989 Archaeological Survey and Testing at Bellows Air Force Station for New Antennas and Trench Lines, Waimanalo, Ko'olaupoko, O'ahu. Prepared for U.S. Army Corps of Engineers. Kailua: Cultural Surveys Hawaii.

Hunt, T. L., AND R. M. Holsen

1991 An early radiocarbon chronology for the Hawaiian Islands: A preliminary analysis. Asian Perspectives 30(1): 147-161.

Hurlbett, R. E., And A. E. Haun

1987 Task Product 4: Cultural Resource Inventory, Evaluation, and Recommendations. Subtask 4A: Inventory and Evaluation. Cultural Resources Management Plan. Bellows Air Force Station, Oahu, Hawaii. Prepared for the U.S. Air Force. Paul H. Rosendahl, Ph.D., Inc., Hilo.

James, H. F., T. W. Stafford, D. W. Steadman, S. L. Olson, P. S. Martin, A. T. Jull, and P. C. McCoy

1987 Radiocarbon dates on bones of extinct birds from Hawai'i, in Proceedings of the National Academy of Science $84: 2350-2354$.

KIRCH, P. V.

1974 The chronology of early Hawaiian settlement. Archaeology and Physical Anthropology in Oceania 9: 110-119.

1982 The impact of the prehistoric Polynesians on the Hawaiian ecosystem. Pacific Science 36(1): $1-14$

1984 Evolution of the Polynesian Chiefdoms. Cambridge: Cambridge University Press.

1985 Feathered Gods and Fishhooks: An Introduction to Hawaiian Archaeology and Prehistory. Honolulu: University of Hawaii Press.

1986 Rethinking East Polynesian prehistory. Journal of the Polynesian Society 95:9-40.

KirCh, P. V., AND J. ElLison

1994 Palaeoenvironmental evidence for human colonization of remote Oceanic islands. Antiquity 68:310-321. 
Masse, B., and D. Tuggle

1998 The date of Hawaiian colonization, in Easter Island in Pacific Context South Seas Symposium: Proceedings of the Fourth International Conference on Easter Island and East Polynesia: 229235, ed. C. M. Stevenson. G. Lee, and F. J. Morin. Easter Island Foundation Occasional Paper 4, Easter Island Foundation. Los Osos, CA: Bearsville and Cloud Mountain Presses.

McCoy, P. C., A. Sinoto, and A. Makanani

1993 Archaeological Investigations of the Pu'u Moiwi Adz Quarry Complex, Kaho'olawe. Report prepared for the Kaho'olawe Conveyance Commission, Wailuku, Maui.

McNeILL, J. R.

1989 Intensive Archaeological Investigations at Site 50-80-15-3709, Bellows Air Force Station, O'ahu, Hawaii. Honolulu: International Archaeological Research Institute, Inc.

Miller, L. O.

1991 Revised Final Report, Archaeological Monitoring of the Tinker Road Bridge Repair (Replacement) Project, Bellows Air Force Station, Waimanalo, O'ahu, Hawai' $i$. Prepared for T. Iida Contracting, Ltd. Honolulu: Public Archaeology Section, Applied Research Group, Bishop Museum.

Murakami, G. M.

1987 Identification of charcoal from Kaho'olawe, appendix $\mathrm{H}$, in Kaho'olawe Excavations, 1982-3, Data Recovery Project, Island of Kaho'olawe, Hawaii, ed. P. H. Rosendahl, A. E. Haun, J. B. Halbig, M. Kaschko, and M. S. Allen. Prepared for Pacific Division, Naval Facilities Engineering Command. Hilo, Hawaii: Paul H. Rosendahl, Ph.D., Inc.

1993 Identification of charcoal from archaeological sites in Kamiloloa, Moloka'i, in Kamiloloa Archaeology: Data Recovery and Site Inventory for a Portion of Kamiloloa, Island of Moloka'i, Hawai' $i$, ed. H. D. Tuggle. Prepared for the Department of Hawaiian Home Lands. Honolulu: International Archaeological Research Institute, Inc.

Pearson, R. J., P. V. Kirch, and M. Pietrusewsky

1971 An early prehistoric site at Bellows Beach, Waimanalo, Oahu, Hawaiian Islands. Archaeology and Physical Anthropology in Oceania 6:204-234.

Rolett, B. V.

1989 University of Hawaii Archaeological Research on Bellows Air Force Station: Report of the 1989 Field School and a Proposal for Further Research in 1990. Honolulu: Department of Anthropology, University of Hawai'i.

19921990 Archaeological Excavations at Site 50-80-15-3300 (Bellows Air Force Station, Oahu). Honolulu: Department of Anthropology, University of Hawai'i.

Sнотт, M. J.

1992 Radiocarbon dating as a probabilistic technique: The Childers Site in Late Woodland occupation in the Ohio Valley. American Antiquity 57(2):202-230.

SHUN, K.

1993 Archaeological Monitoring and Sampling during Emergency Flood Repair Construction, Waimanalo and Inoaole Streams, Bellows Air Force Station, Waimanalo, Koolaupoko District, Island of Oahu, Hawaii. Draft report prepared for the U.S. Army Corps of Engineer District, Honolulu. Kailua: Archaeological Associates Oceania.

Smiley, F. E., AND R.V.N. Ahlstrom

1998 Archaeological Chronometry: Radiocarbon and Tree-Ring Models and Applications from Black Mesa, Arizona. Southern Illinois University at Carbondale, Center for Archaeological Investigations, Occasional Paper No. 16.

SPRIGgS, M.

1987 Report on Radiocarbon Dates from Bellows Air Force Station. Ms. on file, State Historic Preservation Division, Department of Land and Natural Resources, Honolulu.

1989 The dating of the island Southeast Asian Neolithic: An attempt at chronometric hygiene and linguistic correlation. Antiquity 63:587-613.

1991 A Not So Early Prehistoric Site at Bellows Beach, Waimanalo, O‘ahu. Paper presented at the Fourth Annual Conference of the Society for Hawaiian Archaeology, University of Hawai'i at Manoa.

1999 The dating of Non Nok Tha and the "Gakashuin factor," in Ancient Chinese and Southeast Asian Bronze Cultures, Vol. 2:941-948, ed. D. Bulbeck and N. Barnard. Taipei: SMC Publishing. 
Spriggs, M., AND A. ANDERson

1993 Late colonization of East Polynesia. Antiquity 67:200-217.

Stuiver, M., AND P. J. ReImer

1993 Extended ${ }^{14} \mathrm{C}$ data base and revised CALIB $3.0{ }^{14} \mathrm{C}$ age calibration program. Radiocarbon $35: 215-230$.

Tomonari-Tuggle, M. J., H. D. Tuggle, and J. S. Athens

1999 Archaeology on a south coast landscape: Hulopo'e, Lāna'i, Hawai'i, Vol. 1: Background and Synthesis. Prepared for Lanai Company, Inc. Honolulu: International Archaeological Research Institute, Inc.

Tuggle, H. D.

1979 Hawaii, in The Prehistory of Polynesia: 167-199, J. D. Jennings. Cambridge: Harvard University Press.

1997 Archaeological Research of Areas Proposed for Development of Military Family Housing and Expansion of Military Training at Bellows Air Force Station, O'ahu, Literature Review of the Cultural Resources of the Area. Final Report. Prepared for Belt Collins Hawai'i. Honolulu: International Archaeological Research Institute, Inc.

Tuggle, H. D., R. H. Cordy, AND M. Child

1978 Volcanic glass hydration-rind age determinations for Bellows Dune, Hawaii. New Zealand Archaeological Association Newsletter $21: 58-77$.

Tuggle, H. D., AND L. Olson

1978 A Review of "Hydration Dating" of Hawaiian Volcanic Glass. Ms. on file, Historic Preservation Division, Department of Land and Natural Resources, Honolulu.

VANCOUVER, G.

1798 A Voyage of Discovery to the North Pacific Ocean, and Round the World ... Performed in the Years 1790-1795. 3 vols. London: Robinsons and Edwards.

\begin{abstract}
The Bellows Dune site was excavated more than three decades ago (Pearson et al. 1971), and has been generally considered one of the earliest settlement sites in the Hawaiian cultural sequence. More than ten years later, in the now-classic summary of Hawaiian archaeology, Kirch (1985) considered it to be one of only two sites firmly identified as belonging to the Colonization phase in Hawai' $i$. This status has remained largely intact. Working independently, the authors of the present article found problems with the interpretations of the dating of this site. Combining our efforts and reviewing the general debate over the timing of human colonization of the Hawaiian archipelago, we suggest that the oft-quoted early dates for the Bellows site are in error, and that a site-based argument for pre-A.D. 800 settlement of Hawai' $i$ is approaching a case list of zero. The most supportable conclusion is that of the two main layers at O18, the lower one (L. III) pre-dates A.D. 1000, and the upper one (L.II) post-dates A.D. 1000. The Bellows Dune site dating is deconstructed, dates from Bellows that have not been published are presented, the Bellows dates are placed in the context of new information from other sources on the date of Hawaiian colonization, and a new hypothesis for the age of the Bellows Dune site is proposed. KeYwords: Bellows Dune, early settlement, Hawaiian chronology.
\end{abstract}

